RECEBIDO EM 23/05/2014. ACEITO EM 09/11/2014.

\title{
Avaliação de práticas de produção enxuta em células de manufatura no setor automotivo
}

\section{Larissa de Souza Pedrosa Fritzen}

Universidade Federal do Rio Grande do Sul - UFRGS

larissa_pedrosa@hotmail.com

\section{Tarcisio Abreu Saurin}

Universidade Federal do Rio Grande do Sul - UFRGS

saurin@ufrgs.br

\section{RESUMO}

O conceito de produção enxuta é muito difundido e aplicado por empresas de vários setores, especialmente no setor automotivo. O uso de células de manufatura é uma das principais práticas adotadas no contexto dos sistemas de produção enxuta. Este artigo tem como objetivo identificar oportunidade de melhoria em um método de avaliação do uso de práticas enxutas em células de manufatura. Com base para identificar tais oportunidades, o método foi aplicado em uma célula de manufatura de uma empresa automotiva que necessita melhorar seu sistema produtivo para a entrada de novos produtos e suportar o aumento da sua demanda produtiva.

Palavras-chave: Células de manufatura. Produção enxuta. Medição de desempenho.

\section{ABSTRACT:}

The concept of lean production is widespread and applied by companies in various industries, especially in the automotive sector. The use of manufacturing cells is one of the main practices in the context of lean production systems. This article aims to identify opportunities for improvement in a method of evaluating the use of lean practices in manufacturing cells. Basis to identify such opportunities, the method was applied to a manufacturing cell of an automotive company that needs to improve its production system for the entry of new products and support the increase of its production demand.

Keywords: manufacturing cells. Lean production. Performance measurement. 


\section{Introdução}

O setor automotivo caracteriza-se por uma grande competitividade o que exige suprir a demanda com qualidade, eficiência e menor custo, em contextos de frequentes mudanças na estrutura das empresas. (CANGUE et al., 2004). Diante desse cenário, o setor automotivo pode se beneficiar do uso de Sistemas de Produção Enxuta (SPE) ${ }^{1}$, originalmente criado pela Toyota. O princípio básico dos SPE é produzir mais com menor utilização de recursos, como energia e mão de obra. (WOMACK et al., 1998).

Este artigo tem como objetivo identificar oportunidade de melhorias em um método de avaliação das práticas de PE em CM, proposto por Saurin et al. (2011). Tal método foi escolhido por trazer uma visão abrangente das práticas de $\mathrm{PE}$, contemplando àquelas ligadas aos recursos humanos, ao planejamento e controle da produção e as tecnologias de processo. Além disso, o método induz à análise dos relacionamentos entre as práticas, permitindo identificar como melhorias em uma prática impactam em outras. O método de Saurin et al. (2011), até o momento não foi encontrado na literatura em outra aplicação publicada por outros que não sejam os idealizadores do mesmo. Em termos práticos, o trabalho justifica-se, pois a empresa onde o método foi aplicado identificou a necessidade de melhorar o desempenho da célula avaliada, visto que um novo produto deve entrar em produção aumentando a sua demanda. Outro ponto importante é que esta célula, financeiramente, é muito importante para a empresa e, por isso, a entrada de um novo produto requer estudos externos, como o proposto neste artigo; evitando que o reprojeto tenha os mesmos problemas atuais.

\section{2-Referencial Teórico}

\subsection{Células de manufatura no Sistema de Produção Enxuta}

A produção enxuta teve sua origem no setor automobilístico e, posteriormente, foi aplicada em outros setores. É um sistema em que a produção obedece à demanda solicitada. Em contraponto aos sistemas tradicionais de produção, nos quais se produz com base em programas que não necessariamente refletem os deveres reais de cada operação. (SHARMA et al., 2008).

A produção enxuta abrange uma variedade de práticas que incluem, principalmente, sistema de qualidade, trabalho em equipe e células de manufatura em um sistema integrado (SHAH; WARD, 2003). Segundo Riani (2006), é necessária a aplicação das ferramentas para obter os resultados do sistema enxutos. A célula de manufatura ${ }^{2}$ é uma das ferramentas que contribuem com os objetivos da PE.

${ }^{1}$ O SPE tem como uma das suas práticas a organização em células de manufatura, que apresentam benefícios como flexibilidade de mix, baixo tempo de set up, melhor qualidade. (PARK; HAN, 2002). Além disso, outro ponto forte da célula de manufatura é que ela requer postos de trabalho com cargas de trabalho balanceadas e baixo estoque em processo, o que acaba revelando rapidamente suas ineficiências. (WILKES, 2000). Os aspectos citados acima também são importantes de acordo com os princípios da PE.

Wilkes (2000) destaca que a implantação de células de manufatura exige um grande comprometimento de toda a companhia, o que pode exigir mudanças culturais. Fleury (1993) e Wilkes (2000) citam como exemplos dessas mudanças, como a delegação de autonomia e responsabilidade aos níveis operacionais, em termos de controle da qualidade, desenvolvimento de projetos de melhorias, e operação de múltiplas máquinas.

${ }^{2}$ Células de manufatura são agrupamentos de postos de trabalho que possuem uma sequência de etapas de processo, tendo pouco ou nenhum estoque entre as etapas (CONTADOR, 1995) e fabricando produtos da mesma família. Com a implementação das células, verifica-se uma redução do tempo gasto em transferências entre os postos de trabalho, do tempo de preparação das máquinas, da quantidade de ferramentas utilizadas, do tamanho dos lotes e do tempo total de 
O método de Saurin et al. (2011) permite avaliar a utilização de práticas de PE em células de manufatura, mostrando pontos fortes e fracos e identificando oportunidade de melhorias com base na análise das interfaces entre práticas de produção enxuta.

$\mathrm{O}$ método citado também permite avaliar se os atributos de uma $\mathrm{CM}$ existem, quais sejam: tecnologia de grupo, atributo organizacional e conexões de tempo, espaço e informação.

As dezoito práticas de produção enxuta incluídas no método são classificadas em três categorias: Recursos Humanos, Planejamento e Controle da Produção e Tecnologia de Processo. Cada prática possui uma série de atributos, os quais são avaliados com base em fontes de evidências definidas pelo método. Os quadros 1, 2 e 3 apresentam todas as práticas e seus respectivos atributos.

Quadro 1 - Atributos de práticas de produção enxuta no subsistema de recursos humanos.

\begin{tabular}{|l|l|}
\hline Práticas & Atributos \\
\hline $\begin{array}{l}\text { 1. Trabalho em } \\
\text { equipe } \\
\text { liderança (TWL) e }\end{array}$ & $\begin{array}{l}\square \square \text { O líder de equipe auxilia os operadores em atividades de melhoria e } \\
\text { solução de problemas. } \\
\square \text { O líder de equipe substitui os operadores no caso de ausências. } \\
\square \square \text { Os operadores são avaliados pelo desempenho do trabalho da equipe } \\
\text { como um todo. }\end{array}$ \\
\hline $\begin{array}{l}\text { 2. Melhoria } \\
\text { Contínua } \\
\text { (CI) }\end{array}$ & $\begin{array}{l}\square \square \text { Os operadores são treinados em métodos de solução de problemas, } \\
\text { incluindo a ênfase em buscar as causas raízes. } \\
\square \square \text { Há grupos de operadores que se dedicam a atividades de melhoria } \\
\text { contínua, se reunindo periodicamente. } \\
\square \square \text { Os grupos de melhoria contínua são coordenados por operadores ou } \\
\text { líderes. }\end{array}$ \\
\hline $\begin{array}{l}\text { 3.Multifuncionali } \\
\text { dade e prática de } \\
\text { rodízio. (MCT) }\end{array}$ & $\begin{array}{l}\square \text { Todos os operadores são capacitados a realizar todas as operações da } \\
\text { Hán controle da capacitação dos operadores em realizar as operações } \\
\text { da célula (ex: matriz de habilidades). } \\
\square \text { O rodízio entre postos e operações é realizado de modo diário. }\end{array}$ \\
\hline $\begin{array}{l}\text { 4. Autonomia dos } \\
\text { Operadores. } \\
\text { (WAU) }\end{array}$ & $\begin{array}{l}\square \text { Os operadores têm autonomia para identificação e controle de } \\
\text { variaçes. } \\
\text { em os operadores e o líder têm autonomia para parar a linha de produção } \\
\square \square \text { cá dispositivos visuais para solicitar auxílio imediato do líder e ou de }\end{array}$ \\
\hline
\end{tabular}

fabricação. (RIBEIRO; MEGUELATI, 2002). O sistema de produção organizado em células torna-se mais simples e eficiente, apresentando respostas rápidas e qualificadas para as inúmeras demandas de mercado. (CONCEIÇÃO, 2005).

Hyer e Brown (1999) salientam a importância das conexões de tempo, espaço e informação entre os postos de trabalho que compõem as células de manufatura. Os autores definem as conexões como: (a) o tempo de espera e transferência entre operações seqüenciadas deve ser minimizado; (b) o espaço entre as operações realizadas deve ser pequeno; (c) as pessoas responsáveis pela CM devem ter acesso às informações necessárias para o trabalho realizado na CM. 


\begin{tabular}{|c|c|}
\hline & $\begin{array}{l}\text { áreas de apoio (por exemplo: manutenção, pré-setup, engenharia ou } \\
\text { qualidade). }\end{array}$ \\
\hline $\begin{array}{l}\text { 5. Padronização } \\
\text { do } \\
\text { (STW) }\end{array}$ & $\begin{array}{l}\square \square \text { Há um ou mais formulários de padronização das operações. } \\
\square \square \text { O (s) formulário(s) está visível aos operadores e ao líder. } \\
\square \square \text { O (s) formulário (s) descreve as informações de: takt time, tempo de } \\
\text { ciclo, separação de tempo homem e tempo máquina, seqüência de produção, } \\
\text { estoque padrão, desenho do arranjo físico e movimentação dos operadores. } \\
\square \square \mathrm{O} \text { (s) formulário (s) é atualizado regularmente de acordo com as } \\
\text { melhorias realizadas nas operações. } \\
\square \square \mathrm{O} \text { (s) formulário (s) é utilizado para verifica se as operações estão } \\
\text { ocorrendo de acordo com os padrões estipulados. }\end{array}$ \\
\hline $\begin{array}{l}\text { 6. Organização } \\
\text { do } \\
\text { local de trabalho. } \\
\text { (WHK) }\end{array}$ & $\begin{array}{l}\square \square \text { A célula está organizada (tem apenas os objetos necessários), ordenada } \\
\text { (localização clara de cada objeto) e limpa (sem poeira, óleo ou outro tipo de } \\
\text { sujeira). } \\
\square \square \text { Há um programa } 5 \mathrm{~S} \text { com auditorias regulares } \\
\square \square \text { Os resultados das auditorias estão publicados junto à célula. }\end{array}$ \\
\hline
\end{tabular}
Fonte: Saurin et al. (2011).

\section{Quadro 2 - Atributos de práticas de produção enxuta no subsistema de planejamento e} controle da produção.

\begin{tabular}{|c|c|}
\hline Práticas & Atributos \\
\hline $\begin{array}{l}\text { 7. Produção } \\
\text { Puxada. (PULL) }\end{array}$ & $\begin{array}{l}\text { Há limites para os estoques em processo, componentes e produto } \\
\text { acabado da célula. Tais limites são identificados por meio de } \\
\text { dispositivos visuais segundo a lógica de linha } F I F O \text { ou kanban. } \\
\square \square \mathrm{O} \text { atributo anterior existe para todos os produtos, sejam eles } \\
\text { comprados ou fabricados. } \\
\square \square \mathrm{A} \text { alimentação de componentes da célula é realizada com } \\
\text { regularidade e por funcionários dedicados a essa atividade (não pelos } \\
\text { próprios operadores da célula). }\end{array}$ \\
\hline $\begin{array}{l}\text { 8. Nivelamento } \\
\text { de Produção. (SPR) }\end{array}$ & $\begin{array}{l}\square \square \text { Todos os modelos de produtos demandados ao longo do mês são } \\
\text { produzidos todos os dias. } \\
\text { - Consumo de matérias primas ocorre em constantes volumes entre os } \\
\text { processos. }\end{array}$ \\
\hline $\begin{array}{l}\text { 9. Troca rápida } \\
\text { de } \quad \text { ferramentas. } \\
(\mathrm{QST})\end{array}$ & $\begin{array}{l}\square \square \text { A célula não apresenta tempos de setup (por exemplo, na fabricação } \\
\text { de apenas um modelo de produto). } \\
\square \square \text { Caso haja setup, as respectivas atividades são padronizadas, } \\
\text { havendo diferenciação entre atividades internas e externas. }\end{array}$ \\
\hline $\begin{array}{l}10 . \\
\text { Manutenção } \\
\text { produtiva } \\
(\mathrm{TPM})\end{array}$ & $\begin{array}{l}\square \square \text { Os operadores realizam a manutenção preventiva básica e rotineira } \\
\text { (limpeza, lubrificação, ajustes, troca de componentes simples, pequenos } \\
\text { reparos e verificaçôes e inspeções visuais) de forma padronizada em } \\
\text { todos os equipamentos. } \\
\square \square \text { Existe um programa de manutenção planejada preventiva ou } \\
\text { preditiva em todos os equipamentos. }\end{array}$ \\
\hline $\begin{array}{l}\text { 11. Indicadores } \\
\text { enxutos para a } \\
\text { medição de } \\
\text { desempenho. (LME) }\end{array}$ & $\begin{array}{l}\square \square \text { A célula utiliza indicadores que refletem a adoção de princípios da } \\
\text { produção enxuta, tais como: tempo de atravessamento (lead time), FTT } \\
\text { ou índice que leve em consideração retrabalho e refugo, o estoque } \\
\text { planejado versus real e a eficiência do processo (ex: } O E E \text {, no caso de } \\
\text { possuir operações não manuais). }\end{array}$ \\
\hline $\begin{array}{l}\text { 12. Gestão } \\
\text { visual do } \\
\text { controle de } \\
\text { produção. (VPC) }\end{array}$ & $\begin{array}{l}\square \square \text { Há um quadro de controle de produção (manual ou automatizado) } \\
\text { visível aos operadores da célula, indicando a programação de produção } \\
\text { por períodos de horas ou turnos. } \\
\square \square \text { As seguintes informações de controle de produção estão no quadro: } \\
\text { planejado; realizado; saldo pendente; motivos de não atendimento; ações } \\
\text { corretivas }\end{array}$ \\
\hline
\end{tabular}

Fonte: Saurin et al. (2011). 
Quadro 3 - Atributos de práticas de produção enxuta no subsistema de tecnologia de processo.

\begin{tabular}{|c|c|}
\hline Práticas & Atributos \\
\hline $\begin{array}{l}\text { 13. Gestão visual } \\
\text { do controle de } \\
\text { qualidade. (VQC) }\end{array}$ & $\begin{array}{l}\square \square \text { Há quadros de gestão visual do controle da qualidade (manuais ou } \\
\text { automatizados) visíveis aos operadores da célula. } \\
\square \square \text { Os quadros apresentam os índices de qualidade causa raízes para os } \\
\text { defeitos encontrados e respectivos planos de ação. }\end{array}$ \\
\hline $\begin{array}{l}\text { 14. Autonomação } \\
\text { de equipamentos. } \\
\text { (EQA) }\end{array}$ & $\begin{array}{l}\square \square \text { Há uma separação entre o tempo homem e o tempo máquina, de modo } \\
\text { que as máquinas desenvolvam, ao menos parcialmente, operações que } \\
\text { dispensam monitoramento ou ação do operador. Todos os equipamentos } \\
\text { possuem dispositivos poka-yokes para detectar anormalidades (erros ou } \\
\text { defeitos), os quais paralisam a produção e sinalizam sua ocorrência de } \\
\text { forma sonora ou visual. }\end{array}$ \\
\hline $\begin{array}{l}\text { 15. Fluxo unitário. } \\
\text { (ONE) }\end{array}$ & $\begin{array}{l}\square \square \text { As peças são produzidas e transportadas de modo unitário entre } \\
\text { operações, sendo que em cada operação se realiza apenas o que é exigido } \\
\text { pela etapa posterior. }\end{array}$ \\
\hline $\begin{array}{l}\text { 16. Visibilidade e } \\
\text { troca de } \\
\text { informações. (VIS) }\end{array}$ & $\begin{array}{l}\square \square \text { Há visibilidade de todos os operadores em relação a todas as } \\
\text { operações (operadores e equipamentos) e materiais (em fluxo ou em } \\
\text { estoque) alocados na própria célula. } \\
\square \square \text { Todos os operadores podem se comunicar verbalmente em tom de voz } \\
\text { normal. }\end{array}$ \\
\hline $\begin{array}{l}\text { 17. Tamanho e } \\
\text { forma do arranjo } \\
\text { físico. (LSS) }\end{array}$ & $\begin{array}{l}\square \square \text { As dimensões da célula e o arranjo físico permitem que todos os } \\
\text { operadores (no mínimo dois) troquem materiais entre si, sendo exigido } \\
\text { para isso um deslocamento de até um metro de distância. } \\
\square \square \text { Caso tenha apenas um operador, o arranjo físico permite que a célula } \\
\text { opere com mais de um operador e obedece ao atributo anterior. }\end{array}$ \\
\hline $\begin{array}{l}\text { 18. Organização } \\
\text { em fluxo } \\
\text { dominante. (ODF) }\end{array}$ & $\begin{array}{l}\square \text { Todos os produtos que são produzidos na célula passam pelos mesmos } \\
\text { processos seguindo o mesmo fluxo de produção. }\end{array}$ \\
\hline
\end{tabular}

Fonte: Saurin et al. (2011).

Tendo em vista orientar a coleta de dados, Saurin et al. (2011) desenvolveram formulários com 30 questões, distribuídas em quatro seções:

a) A primeira parte se refere à empresa, buscando informações sobre o porte, segmento que atua e seus produtos;

b) A segunda aborda as características da célula, como o número de colaboradores, os equipamentos e produtos;

c) A terceira trata das conexões entre espaço, tempo e informações;

d) Já a quarta trata da construção da matriz de produto e processo, avaliando o uso de tecnologia de grupo.

A figura 1 apresenta o modelo de relacionamento entre as práticas de PE, não contendo somente as práticas automação de equipamentos (EQA) e indicadores enxutos para a medição de desempenho (LME), visto que essas práticas não apresentaram relações fortes de dependência com as demais. Com base na figura 1, pode-se observar que as práticas são classificadas como: básicas, intermediárias e finais. Os autores definem que (a) práticas básicas apoiam outras práticas pelo menos duas vezes mais do que dependem de outras práticas; (b) práticas intermediárias dependem tanto de outras práticas como outras práticas dependem delas; (c) práticas 
finais dependem das outras práticas pelo menos o dobro do que elas suportam outras práticas.

Figura 1 - Modelo de relacionamento das práticas de produção enxuta.

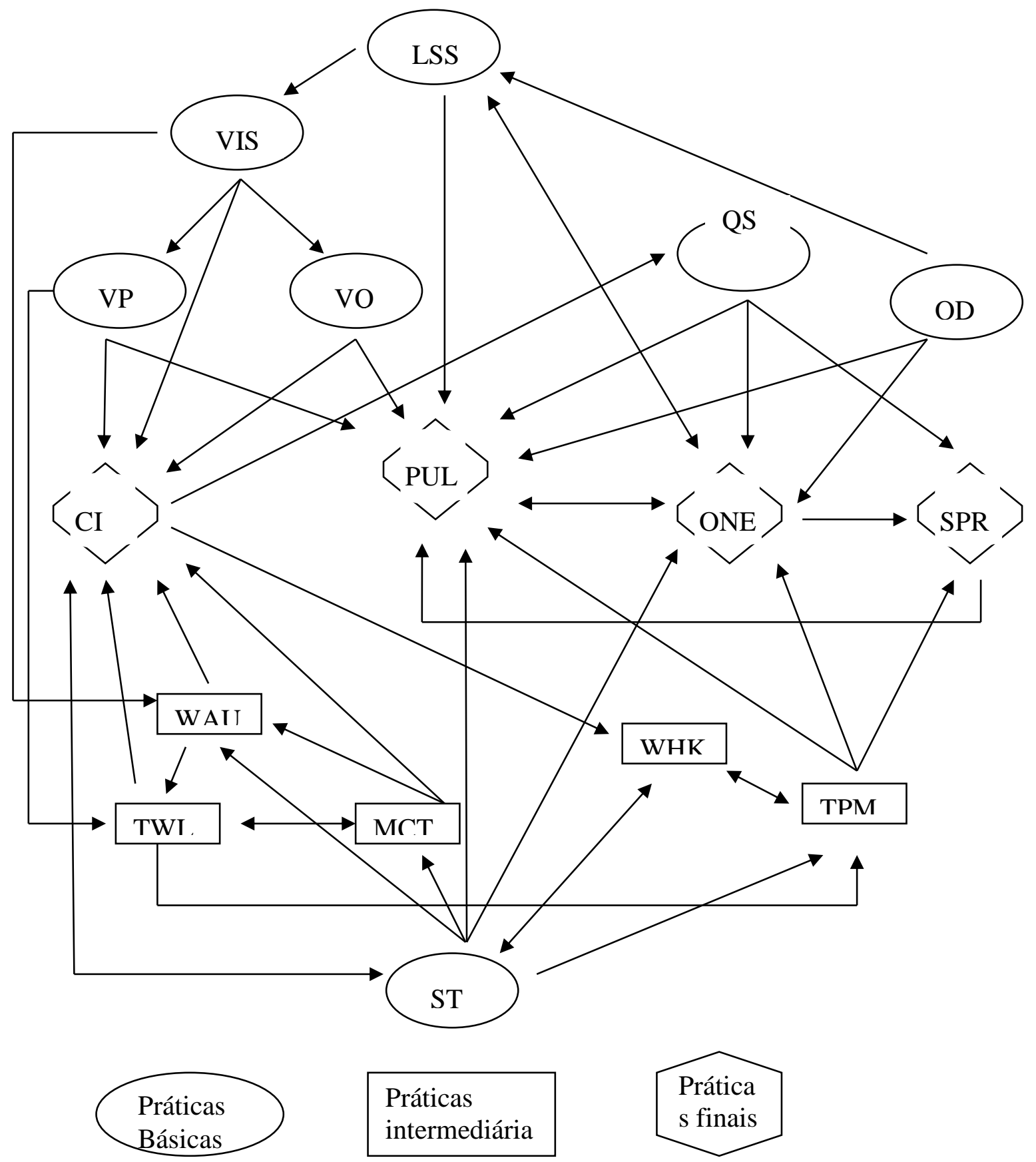

Fonte: Saurin et al. (2011).

\section{Método de pesquisa}

O planejamento deste estudo foi dividido da seguinte forma: a) revisão da bibliografia acerca de CM e SPE; b) escolha do método de avaliação do uso de PE em CM e melhoria do mesmo; c) escolha da empresa e da célula para aplicar o método; d) organização da aplicação do método de avaliação da célula. Após o planejamento, ocorreu a etapa de aplicação do método de avaliação da célula, em que foi definido o planejamento da aplicação das 
avaliações da existência dos atributos de $\mathrm{CM}$, do uso das práticas de $\mathrm{PE}$ e dos relacionamentos entre as práticas.

\subsection{Melhorias no método Saurin}

Antes de aplicar o método de Saurin et al. (2011), foram identificadas oportunidades de aperfeiçoamento no mesmo. Assim, foram incorporados atributos associados à ergonomia e segurança no trabalho, no âmbito da categoria de práticas Recursos Humanos (Quadro 4). De fato, conforme Gary (2003) e Gonçalves Filho et al. (2011), a prevenção de acidentes e doenças ocupacionais deve ser um dos objetivos relevantes de empresas que implementam a PE.

\section{Recursos Humanos}

Quadro 4 - Atributos de segurança no trabalho e ergonomia propostos como acréscimo ao método de Saurin.

\begin{tabular}{|c|c|c|}
\hline Praticas & Atributos & Fontes \\
\hline $\begin{array}{l}\text { 7. Segurança e } \\
\text { ergonomia. (SE) }\end{array}$ & $\begin{array}{l}\square \square \text { Auditorias realizadas pelo o time de } \\
\text { apoio avaliando as questões de segurança e } \\
\text { ergonomia em cada processo na linha de } \\
\text { produção } \\
\square \square \text { Há quadros de controles visuais dos } \\
\text { controles de segurança e ergonomia. } \\
\text { Indicadores proativos, identificando os } \\
\text { problemas antes que eles aconteçam e } \\
\text { indicadores corretivos. } \\
\square \square \text { O líder conduz as melhorias contínuas } \\
\text { para ergonomia e segurança. }\end{array}$ & $\begin{array}{l}\text { - Garcia (2004) e } \\
\text { Gonçalves Filho et } \\
\text { al. (2011) } \\
\text { - Gary (2003) } \\
\text { - Gonçalves Filho et } \\
\text { al. (2011) }\end{array}$ \\
\hline
\end{tabular}
Fonte: Fritzen (2013).

Como outro aperfeiçoamento de método de Saurin et al. (2011), foram estabelecidas pontuações para os diferentes níveis de atendimento de cada atributo. Assim, o atributo que está plenamente conforme recebe a pontuação 2; o que está parcialmente conforme recebe a pontuação 1; o que não está conforme recebe a pontuação 0 e as práticas que não são aplicáveis ao estudo não recebem pontuação. A pontuação de cada prática é calculada a partir da soma das pontuações de cada atributo, dividida pelo total de pontos possíveis em cada prática.

\subsection{Critérios de escolha da empresa e da célula de manufatura}

Os critérios levados em consideração para a escolha da empresa estudada foram os seguintes: a) planta automotiva de grande porte, setor no qual teve início a produção enxuta; b) planta que opera segundo a filosofia da produção enxuta e que tenha um método de implementação desta filosofia.

Após a escolha da planta, foi escolhida uma célula. O principal critério de escolha foi o fato de que um novo produto seria introduzido na mesma, criando então, oportunidade para aplicação de uma diretriz de reprojeto de CM proposto como objetivo principal dessa dissertação.

\subsection{Aplicação do método de avaliação da célula}

No início da avaliação, a CM foi observada pelo analista de processo durante uma semana, com o objetivo de verificar pontos que pudessem comprometer o estudo e avaliar a existência dos atributos da CM. Foi observado seu funcionamento através do trabalho padrão 
dos operadores e atividades do líder de produção, como o abastecimento das matérias primas. Com as movimentações, verificou-se o layout das máquinas e tempos de ciclos de cada operação. Outro ponto observado foi os quadros de controles de produção, identificando a metodologia adotada para transmitir as informações coletadas na CM.

Para o funcionamento da célula são necessários dois operadores e um líder de produção em cada turno. Desses, somente dois operadores e um líder foram entrevistados como parte da coleta de dados para aplicação do método, uma vez que eles possuem mais de cinco anos de trabalho na célula, possuindo maior conhecimento acerca de suas rotinas. O gerente da produção e o analista de qualidade também foram entrevistados para aplicação do método, tendo em vista que os dois possuem uma visão sistêmica do negócio, além de conhecimento no assunto SPE.

Antes da aplicação dos formulários de avalição do uso das práticas de PE, verificouse a importância da realização de uma reunião para explicar aos participantes o objetivo do estudo. Durante o encontro foram apresentadas as tabelas que definem os atributos de recursos humanos, planejamento e controle da produção e tecnologia do processo, além do questionário a ser aplicado (Apêndice A, B, C e D). Foram esclarecidas as diferenças entre o método adotado pela empresa para avaliar a célula e o método usado na pesquisa.

Após a reunião de esclarecimento do método, com duração de uma hora e meia, o questionário foi entregue às pessoas selecionadas. Ao invés do método de Saurin et al. (2011), em que as entrevistas foram feitas no local, os colaboradores levaram o questionário para suas casas, para que tivessem tempo hábil de responder as questões propostas. Essa medida foi tomada também porque a gerência tinha receio de que este trabalho prejudicasse o andamento da produção. Todos entregaram o questionário uma semana após a reunião de esclarecimento.

A engenharia de processo analisou os questionários de uso das práticas de PE dos participantes. Logo após o resultado, foram avaliados relacionamentos entre as práticas de PE. Estas análises tiveram uma duração de dois meses, em que foram apresentadas para o time participante em uma reunião de resultados. Com base nos resultados do estudo, foram discutidas as melhorias identificadas. Todos concordaram com os resultados apresentados, debatendo as questões de maior pontuação.

\section{Resultados e discussões}

\subsection{Características da empresa e da célula estudada}

Fundada em 1904 a empresa multinacional é sediada na cidade de Maumee, Ohio, nos Estados Unidos. Atua em 26 países, nos quais emprega 25.000 colaboradores em todas as suas unidades. Há 63 anos no Brasil, a empresa mantém 13 unidades industriais e dois Centros de Serviços Compartilhados, em Gravataí, no Rio Grande do Sul, em Diadema, em Sorocaba, no interior de São Paulo.

A planta onde está presente a célula em estudo se localiza em Gravataí no estado do Rio Grande do Sul e possui cerca de 200 funcionários diretos, sendo 150 operadores na produção. Atendendo o mercado nacional e internacional, seus principais produtos são módulos de vedação que tem como matéria prima o metal, o plástico e a borracha. $\mathrm{O}$ faturamento desta planta representa 7,5\% do faturamento da empresa no Brasil, chegando a $\mathrm{R} \$ 65$ milhões em 2011.

Dentro desta planta, foi escolhida a célula mais evoluída em seu sistema de produção. Esta célula produz tampas de válvula em termoplástico, material polimérico que a torna mais leve e econômica para carros de passeio. Nessa célula, práticas de produção enxuta vêm sendo aplicadas há sete anos.

A célula possui dez operações, sendo conduzidas por dois colaboradores e um líder de produção, em cada turno. Conforme a figura 2, a primeira célula funciona com seis operações: injeção de plástico, rosca, montagem de inserto metálico, montagem de estampados e inserção de silicone. Já a segunda célula possui quatro operações: montagem de junta de vedação, parafusos, tampa de óleo e válvula e um teste final de vazamento. A célula 
opera em dois turnos, fabricando produtos que seguem diretamente para a expedição. A produção diária é de setecentas peça

Figura 2 - Layout da célula de manufatura em estudo.

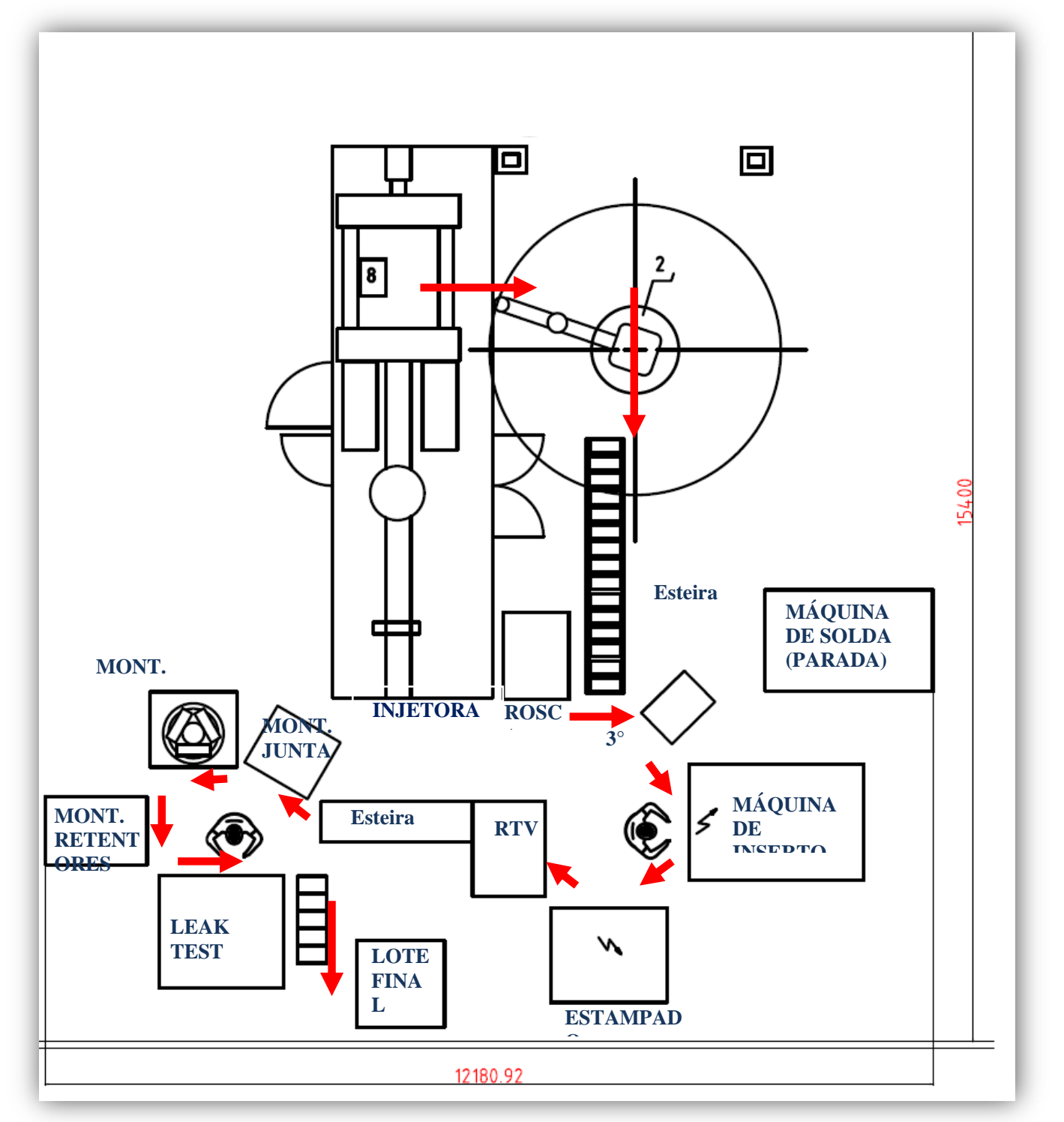

Fonte: Fritzen (2013).

Nota: As setas significam o fluxo de materiais.

\subsection{Método de avaliação de células de manufatura usado na empresa em estudo}

Conforme mencionado, a empresa possui o seu próprio método de avaliação de células de manufatura. Os especialistas do método, que estão alocados na unidade central da empresa, visitam as unidades uma vez por ano para verificar se as práticas de produção enxuta estão sendo bem aplicadas. Com uma periodicidade diária, a eficácia das práticas de PE também é avaliada por meio de indicadores de desempenho, cujos resultados são expostos em um quadro de controle. 
Figura 3 - Quadro de controle da CM.

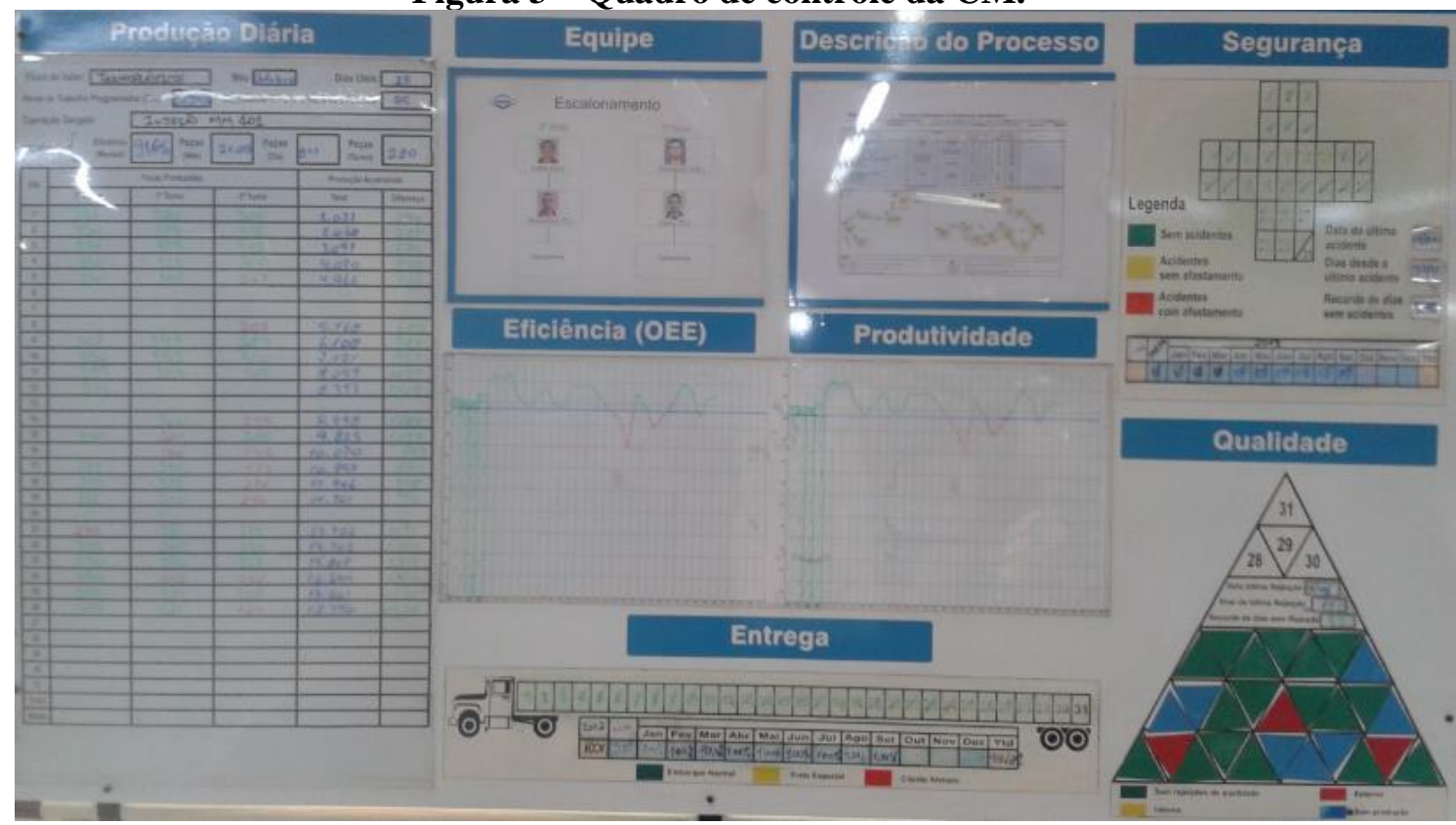

Fonte: Elaborado pela autora.

Os indicadores usados são os seguintes: a entrega, a segurança, a qualidade, a produtividade e a eficiência. Apesar de todos indicadores serem controlados pela manufatura, cada um possui um responsável da área de apoio para monitorar o desempenho.

$\mathrm{O}$ indicador de entrega corresponde à área de programação e controle da produção e seu resultado é controlado visualmente através de cores: verde (entrega no prazo), amarelo (entrega no prazo via frete aéreo) e vermelho (não entregou para o cliente). O controle de segurança corresponde à área de segurança do trabalho, controlando os acidentes, incidentes, e a prevenção de acidentes. Tem como meta zero acidente por ano e também é controlado na CM através de cores: verde (não acidentes), amarelo (incidentes) e vermelho (acidentes). Os incidentes ou quase acidente, são todas as ocorrências que se verificam no dia a dia de trabalho, não atingindo as pessoas e não ocasionando danos à propriedade. $\mathrm{O}$ acidente é aquele que provoca lesão corporal ou perturbação funcional, que causa a redução permanente ou temporária da capacidade para o trabalho.

O controle de qualidade avalia a sucata e as reclamações de clientes da CM. São controladas em um quadro de controle as reclamações de clientes por dia, em que: verde não possui reclamação e vermelho possui reclamação. A sucata da CM é discutida nas reuniões diárias de produção e tem como meta $0,166 \%$ por ano. Os indicadores de produtividade e OEE são controles da produção, em que a produtividade está ligada a eficiência dos processos, tratando da utilização dos recursos para gerar produtos e serviços. Seu cálculo e feito da seguinte forma: número de peça por hora, dividido pelo tempo disponível para a produção. O OEE é o resultado do produto entre os fatores: disponibilidade, performance e qualidade. Conforme o quadro 5, o time de apoio utiliza ferramentas que contribuem no monitoramento dos resultados dos indicadores.

Quadro 5 - Ferramentas que contribuem no monitoramento dos resultados dos indicadores.

\begin{tabular}{|c|c|c|c|c|c|}
\cline { 2 - 6 } \multicolumn{1}{c|}{} & \multicolumn{5}{c|}{ Indicadores } \\
\hline Ferramentas & Entrega & OEE & Produtividade & Segurança & Qualidade \\
\hline Dowtime (paradas não & $\mathrm{X}$ & $\mathrm{x}$ & $\mathrm{x}$ & & \\
\hline
\end{tabular}




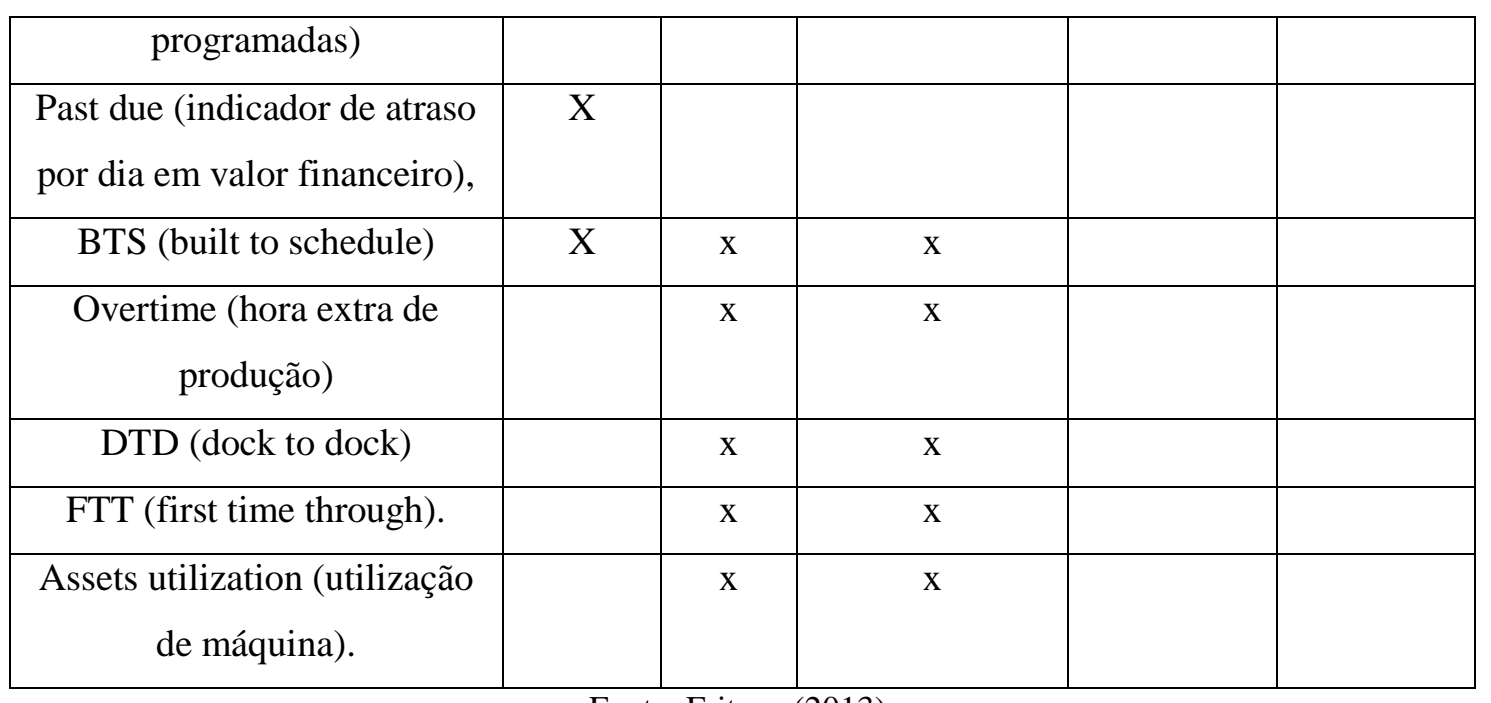

Fonte: Fritzen (2013).

\subsection{Avaliação da existência dos atributos CM}

Nesta etapa da pesquisa foi avaliado se a célula aderia às características de célula de manufatura descritas na secção 2.2 deste artigo. Observou-se que as operações são diferentes e sequenciais, e que é dedicada a uma família de produtos. A CM possui um layout compacto, que diminui as caminhadas dos operadores e transferências de materiais. Esse layout também contribui para um curto tempo de espera entre uma operação e outra. A célula está separada por um túnel de resfriamento, por motivos de tecnologia de processo. O túnel também ajuda no balanceamento da célula, pois os tempos de ciclos das operações são diferentes.

Em relação às conexões de informação, há documentação em local de fácil acesso e visibilidade, mostrando os procedimentos operacionais padronizados e especificações técnicas dos produtos. Além disso, a célula também possui quadros com indicadores que mostram os resultados do dia a dia de qualidade, produção e segurança.

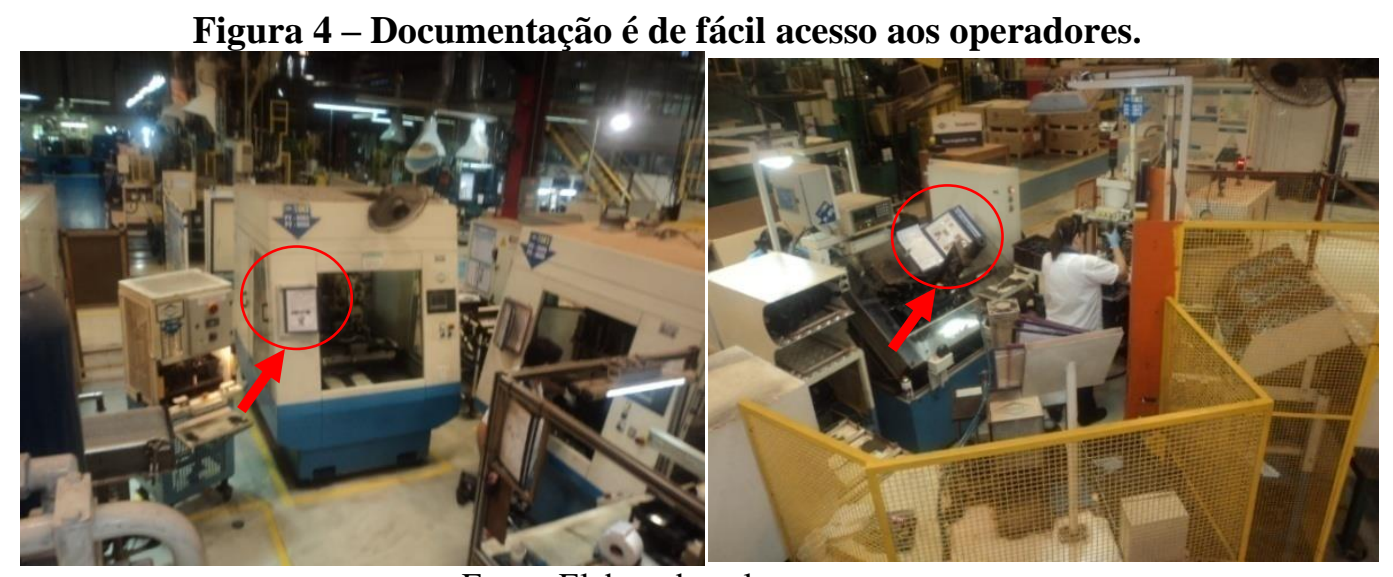

Fonte: Elaborado pela autora.

A CM possui metas de desempenho que são controladas pelo líder de produção, que também contam com um gerente de produção e supervisor de produção. O líder é o responsável por coordenar os operadores e também dar o suporte técnico imediato, como soluções para problemas de primeiro nível. Junto ao líder, na área de suporte técnico, há um analista de processo que é envolvido em todas as documentações, melhorias e desenvolvimentos. Também há um analista da qualidade que se envolve com as auditorias de qualidade e reclamações de cliente. 
Os quadros 6, 7 e 8 apresentam na terceira coluna, os resultados acerca da existência dos atributos das práticas de PE na célula avaliada e na quarta coluna o resultado da pontuação de cada prática. O quadro 9 apresenta em uma tabela o resumo da pontuação que cada prática obteve, conforme a secção 3.2.

\section{Recursos Humanos}

Quadro 6 - Análise dos atributos de produção enxuta no subsistema de recursos humanos da célula de manufatura em estudo.

\begin{tabular}{|c|c|c|c|}
\hline Práticas & Atributos & \begin{tabular}{ll|}
$\begin{array}{l}\text { Resultados } \\
\text { atributos }\end{array}$ & dos \\
verificados & na \\
célula & \\
\end{tabular} & $\begin{array}{l}\text { Pontuação } \\
\text { das práticas } \\
\text { de PE }\end{array}$ \\
\hline $\begin{array}{l}\text { 1. Trabalho em } \\
\text { equipe e liderança } \\
\text { (TWL) }\end{array}$ & $\begin{array}{l}\text { a) O líder de equipe auxilia } \\
\text { os operadores em atividades } \\
\text { de melhoria e solução de } \\
\text { problemas. } \\
\text { b) O líder de equipe substitui } \\
\text { os operadores no caso de } \\
\text { ausências. } \\
\text { c) Os operadores são } \\
\text { avaliados pelo desempenho } \\
\text { do trabalho da equipe como } \\
\text { um todo. }\end{array}$ & \begin{tabular}{lr} 
a) O líder & é o \\
responsável & pelas \\
atividades & de \\
melhoria e & solução \\
\multicolumn{2}{c}{ de problemas }
\end{tabular} & $\begin{array}{l}\text { a) } 1 \mathrm{pt} \\
\text { b) } 2 \mathrm{pts} \\
\text { c) } 2 \mathrm{pts}\end{array}$ \\
\hline $\begin{array}{l}\text { 2. Melhoria } \\
\text { Contínua (CI) }\end{array}$ & $\begin{array}{l}\text { a) Os operadores são } \\
\text { treinados em métodos de } \\
\text { solução de problemas, } \\
\text { incluindo a ênfase em buscar } \\
\text { as causas raízes. } \\
\text { b) Há grupos de operadores } \\
\text { que se dedicam a atividades } \\
\text { de melhoria contínua, se } \\
\text { reunindo periodicamente. } \\
\text { c) Os grupos de melhoria } \\
\text { contínua são coordenados por } \\
\text { operadores ou líderes. }\end{array}$ & 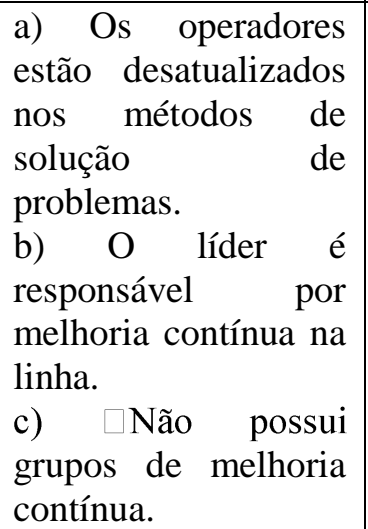 & $\begin{array}{l}\text { a) } 1 \mathrm{pt} \\
\text { b) } 1 \mathrm{pt} \\
\text { c) } 0 \mathrm{pts}\end{array}$ \\
\hline $\begin{array}{l}\text { 3.Multifuncionalidade } \\
\text { e prática de rodízio } \\
\text { (MCT) }\end{array}$ & $\begin{array}{l}\text { a) Todos os operadores são } \\
\text { capacitados a realizar todas } \\
\text { as operações da célula. } \\
\text { b) Há um controle da } \\
\text { capacitação dos operadores } \\
\text { em realizar as operações da } \\
\text { célula (ex: matriz de } \\
\text { habilidades). } \\
\text { c) O rodízio entre postos e } \\
\text { operações é realizado de } \\
\text { modo diário. }\end{array}$ & $\begin{array}{lr}\text { a) Todos } & \text { os } \\
\text { operadores } & \text { são } \\
\text { treinados em todos os } \\
\text { postos, mais r falta } \\
\text { experiência } & \text { nas } \\
\text { máquinas. } & \\
\text { c) A linha não possui } \\
\text { rodízio entre postos }\end{array}$ & $\begin{array}{l}\text { a) } 1 \mathrm{pt} \\
\text { b) } 2 \mathrm{pts} \\
\text { c) } 0 \mathrm{pts}\end{array}$ \\
\hline $\begin{array}{l}\text { 4. Autonomia dos } \\
\text { Operadores (WAU) }\end{array}$ & $\begin{array}{l}\text { a) Os operadores têm } \\
\text { autonomia para identificação } \\
\text { e controle de variações. } \\
\text { b) Os operadores e o líder }\end{array}$ & $\begin{array}{l}\text { b) } \square \text { O líder é o único } \\
\text { com autonomia para } \\
\text { parar a linha de } \\
\text { produção em caso de }\end{array}$ & $\begin{array}{l}\text { a) } 2 \mathrm{pts} \\
\text { b) } 1 \mathrm{pt} \\
\text { c) } 0 \mathrm{pts}\end{array}$ \\
\hline
\end{tabular}




\begin{tabular}{|c|c|c|c|}
\hline & $\begin{array}{l}\text { têm autonomia para parar a } \\
\text { linha de produção em caso de } \\
\text { anormalidades. } \\
\text { c) Há dispositivos visuais } \\
\text { para solicitar auxílio imediato } \\
\text { do líder e ou de áreas de } \\
\text { apoio (por exemplo: } \\
\text { manutenção, pré-setup, } \\
\text { engenharia ou qualidade). }\end{array}$ & $\begin{array}{l}\text { anormalidades. } \\
\text { c) } \square \text { ão } \square \text { há } \\
\text { dispositivos visuais } \\
\text { para solicitar auxílio } \\
\text { imediato do líder e } \\
\text { das áreas suporte }\end{array}$ & \\
\hline $\begin{array}{l}\text { 5. Padronização } \\
\text { do trabalho (STW) }\end{array}$ & $\begin{array}{l}\square \text { Há um ou mais } \\
\text { formulários de padronização } \\
\text { das operações. } \\
\text { a) O (s) formulário (s) está } \\
\text { visível aos operadores e ao } \\
\text { líder. } \\
\text { b) O (s) formulário (s) } \\
\text { descreve as informações de: } \\
\text { takt time, tempo de ciclo, } \\
\text { separação de tempo homem e } \\
\text { tempo máquina, sequência de } \\
\text { produção, estoque padrão, } \\
\text { desenho do arranjo físico e } \\
\text { movimentação } \\
\text { operadores. } \\
\text { c) O (s) formulário (s) é } \\
\text { atualizado regularmente de } \\
\text { acordo com as melhorias } \\
\text { realizadas nas operações. } \\
\text { d) O (s) formulário (s) é } \\
\text { utilizado para verifica se as } \\
\text { operações estão ocorrendo de } \\
\text { acordo com os padrões } \\
\text { estipulados. }\end{array}$ & $\begin{array}{lrr}\text { c) } \square \text { Os formulários } \\
\text { necessitam } & \text { de } \\
\text { melhorias } & \text { na } & \text { sua } \\
\text { atualização } & & \end{array}$ & $\begin{array}{l}\text { a) } 2 \mathrm{pts} \\
\text { b) } 2 \mathrm{pts} \\
\text { c) } 1 \mathrm{pt} \\
\text { d) } 2 \mathrm{pts}\end{array}$ \\
\hline $\begin{array}{l}\text { 6. Organização do } \\
\text { local de trabalho } \\
\text { (WHK) }\end{array}$ & $\begin{array}{l}\text { a) A célula está organizada } \\
\text { (tem apenas os objetos } \\
\text { necessários), ordenada } \\
\text { (localização clara de cada } \\
\text { objeto) e limpa (sem poeira, } \\
\text { óleo ou outro tipo de sujeira). } \\
\text { b) Há um programa 5S com } \\
\text { auditorias regulares } \\
\text { c) Os resultados das } \\
\text { auditorias estão publicados } \\
\text { junto à célula. }\end{array}$ & $\begin{array}{l}\square \square \text { Neste requisito a } \\
\text { célula está com seus } \\
\text { procedimentos } \\
\text { conforme }\end{array}$ & $\begin{array}{l}\text { a) } 2 \mathrm{pts} \\
\text { b) } 2 \mathrm{pts} \\
\text { c) } 2 \mathrm{pts}\end{array}$ \\
\hline $\begin{array}{l}\text { 7. } \quad \text { Segurança } \\
\text { ergonomia. }(\mathrm{SE})\end{array}$ & $\begin{array}{l}\text { a)Auditorias realizadas pelo o } \\
\text { time de apoio avaliando as } \\
\text { questões de segurança e } \\
\text { ergonomia em cada processo } \\
\text { na linha de produção. } \\
\text { b)Há quadros de controles } \\
\text { visuais dos controles de } \\
\text { segurança. Indicadores } \\
\text { proativos, identificando os } \\
\text { problemas antes que eles }\end{array}$ & $\begin{array}{lr}\text { a) } \square \mathrm{s} & \text { operadores } \\
\text { indicaram } & \text { que } \\
\text { necessitam melhorias } \\
\text { na área } & \text { de } \\
\text { ergonomia, res } & \text { pois } \\
\text { sentem dores nos } \\
\text { corpos. } & \\
\text { a) } \square \text { célula } & \text { possui } \\
\text { auditorias } & \text { de } \\
\text { ergonomia, mas } & \text { o } \\
\end{array}$ & $\begin{array}{l}\text { a) } 1 \mathrm{pt} \\
\text { b) } 2 \mathrm{pts} \\
\text { c) } 2 \mathrm{pts}\end{array}$ \\
\hline
\end{tabular}




\begin{tabular}{|l|l|lr|r|}
\hline & aconteça em indicadores & trabalho ainda & \\
corretivos & necessita & de \\
c) O líder conduz as & melhorias. & & \\
melhorias contínuas para & & \\
ergonomia e segurança. & & \\
\hline
\end{tabular}

Fonte: Fritzen (2013).

Planejamento e controle da produção

Quadro 7 - Análise dos atributos de produção enxuta no subsistema planejamento e controle da produção da célula de manufatura em estudo.

\begin{tabular}{|c|c|c|c|}
\hline Práticas & Atributos & \begin{tabular}{|ll} 
Resultados & dos \\
atributos & \\
verificados & na \\
célula & \\
\end{tabular} & $\begin{array}{l}\text { Pontuação das } \\
\text { práticas de PE }\end{array}$ \\
\hline $\begin{array}{l}\text { 8. Produção } \\
\text { Puxada } \\
\text { (PULL) }\end{array}$ & $\begin{array}{l}\text { a) Há limites para os estoques em } \\
\text { processo, componentes e produto } \\
\text { acabado da célula. Tais limites são } \\
\text { identificados por meio de dispositivos } \\
\text { visuais segundo a lógica de linha FIFO } \\
\text { ou kanban. } \\
\text { b) O atributo anterior existe para todos } \\
\text { os produtos, sejam eles comprados ou } \\
\text { fabricados. } \\
\text { c) A alimentação de componentes da } \\
\text { célula é realizada com regularidade e } \\
\text { por funcionários dedicados a essa } \\
\text { atividade (não pelos próprios } \\
\text { operadores da célula). }\end{array}$ & $\begin{array}{l}\square \square \text { Neste requisito } \\
\text { a célula esta com } \\
\text { seus } \\
\text { procedimentos } \\
\text { conforme. }\end{array}$ & $\begin{array}{l}\text { a) } 2 \mathrm{pts} \\
\text { b) } 2 \mathrm{pts} \\
\text { c) } 2 \mathrm{pts}\end{array}$ \\
\hline $\begin{array}{l}9 . \\
\text { Nivelamento } \\
\text { de Produção } \\
\text { (SPR) }\end{array}$ & $\begin{array}{l}\text { a) Todos os modelos de produtos } \\
\text { demandados ao longo do mês são } \\
\text { produzidos todos os dias. } \\
\text { b) Consumo de matérias primas } \\
\text { ocorre em constantes volumes } \\
\text { entre os processos. }\end{array}$ & $\begin{array}{l}\square \square \text { Neste requisito } \\
\text { a célula esta com } \\
\text { seus } \\
\text { procedimentos } \\
\text { conforme }\end{array}$ & $\begin{array}{l}\text { a) } 2 \mathrm{pts} \\
\text { b) } 2 \mathrm{pts}\end{array}$ \\
\hline $\begin{array}{l}10 . \quad \text { Troca } \\
\text { rápida } \\
\text { de } \\
\text { ferramentas } \\
(\mathrm{QST})\end{array}$ & $\begin{array}{l}\text { a ) A célula não apresenta tempos de } \\
\text { setup (por exemplo, na fabricação de } \\
\text { apenas um modelo de produto). } \\
\text { b) Caso haja setup, as respectivas } \\
\text { atividades são padronizadas, havendo } \\
\text { diferenciação entre atividades internas } \\
\text { e externas. }\end{array}$ & $\begin{array}{l}\square \square \text { Neste requisito } \\
\text { a célula esta com } \\
\text { seus } \\
\text { procedimentos } \\
\text { conforme }\end{array}$ & a) $2 \mathrm{pts}$ \\
\hline $\begin{array}{l}11 . \\
\text { Manutenção } \\
\text { produtiva } \\
\text { total (TPM) }\end{array}$ & 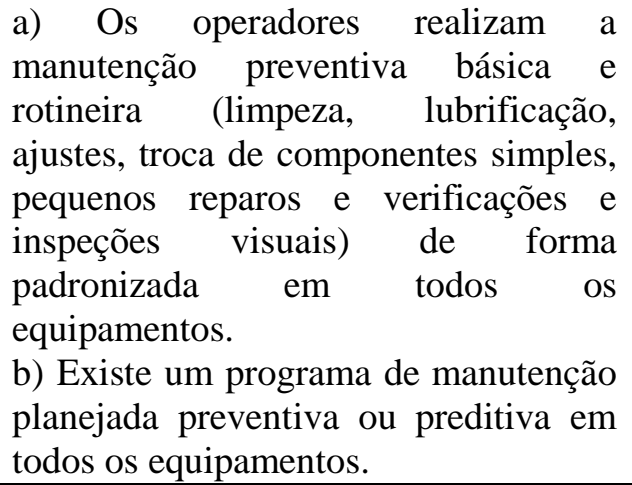 & $\begin{array}{l}\text { a) } \square \text { Alguns } \\
\text { equipamentos da } \\
\text { área de montagem } \\
\text { não possuem } \\
\text { manutenção } \\
\text { preventiva. }\end{array}$ & $\begin{array}{l}\text { a) } 2 \mathrm{pts} \\
\text { b) } 1 \mathrm{pt}\end{array}$ \\
\hline 12. & a) A célula utiliza indicadores que & a) $\square$ Não & a) $1 \mathrm{pt}$ \\
\hline
\end{tabular}




\begin{tabular}{|c|c|c|c|}
\hline $\begin{array}{l}\text { Indicadores } \\
\text { enxutos para } \\
\text { a } \\
\text { medição de } \\
\text { desempenho } \\
\text { (LME) }\end{array}$ & $\begin{array}{l}\text { refletem a adoção de princípios da } \\
\text { produção enxuta, tais como: tempo de } \\
\text { atravessamento (lead time), FTT ou } \\
\text { índice que leve em consideração } \\
\text { retrabalho e refugo, o estoque } \\
\text { planejado versus real e a eficiência do } \\
\text { processo (ex: } O E E \text {, no caso de possuir } \\
\text { operações não manuais). }\end{array}$ & $\begin{array}{l}\text { indicadores de lead } \\
\text { time e estoque } \\
\text { planejado versus } \\
\text { real }\end{array}$ & \\
\hline $\begin{array}{l}\text { 13. Gestão } \\
\text { visual do } \\
\text { controle de } \\
\text { produção } \\
\text { (VPC) }\end{array}$ & $\begin{array}{l}\text { a) Há um quadro de controle de } \\
\text { produção (manual ou automatizado) } \\
\text { visível aos operadores da célula, } \\
\text { indicando a programação de produção } \\
\text { por períodos de horas ou turnos. } \\
\text { b) As seguintes informações de } \\
\text { controle de produção estão no quadro: } \\
\text { planejado; realizado; saldo pendente; } \\
\text { motivos de não atendimento; ações } \\
\text { corretivas. }\end{array}$ & $\begin{array}{l}\square \square \text { Neste requisito } \\
\text { a célula esta com } \\
\text { seus } \\
\text { procedimentos } \\
\text { conforme. }\end{array}$ & $\begin{array}{l}\text { a) } 2 \mathrm{pts} \\
\text { b) } 2 \mathrm{pts}\end{array}$ \\
\hline
\end{tabular}

Fonte: Fritzen (2013).

\section{Tecnologia de processo}

Quadro 8 - Análise dos atributos de produção enxuta no subsistema tecnologia de processo da célula de manufatura em estudo.

\begin{tabular}{|c|c|c|c|}
\hline Práticas & Atributos & \begin{tabular}{|lr}
$\begin{array}{l}\text { Resultados } \\
\text { atributos }\end{array}$ & dos \\
verificados & na \\
célula & \\
\end{tabular} & $\begin{array}{l}\text { Pontuação das } \\
\text { práticas de PE }\end{array}$ \\
\hline $\begin{array}{l}\text { 14. Gestão } \\
\text { visual } \\
\text { do controle de } \\
\text { qualidade } \\
\text { (VQC) }\end{array}$ & $\begin{array}{l}\text { a) Há quadros de gestão visual do } \\
\text { controle da qualidade (manuais ou } \\
\text { automatizados) visíveis aos } \\
\text { operadores da célula. } \\
\text { b) Os quadros apresentam os índices } \\
\text { de qualidade causa raízes para os } \\
\text { defeitos encontrados e respectivos } \\
\text { planos de ação. }\end{array}$ & $\begin{array}{l}\square \square \text { Neste requisito } \\
\text { a célula esta com } \\
\text { seus } \\
\text { procedimentos } \\
\text { conforme. }\end{array}$ & $\begin{array}{l}\text { a) } 2 \mathrm{pts} \\
\text { b) } 2 \mathrm{pts}\end{array}$ \\
\hline $\begin{array}{l}15 . \\
\text { Autonomação } \\
\text { de } \\
\text { equipamentos } \\
\text { (EQA) }\end{array}$ & $\begin{array}{l}\text { a) Há uma separação entre o tempo } \\
\text { homem e o tempo máquina, de modo } \\
\text { que as máquinas desenvolvam, ao } \\
\text { menos parcialmente, operações que } \\
\text { dispensam monitoramento ou ação } \\
\text { do operador. Todos os equipamentos } \\
\text { possuem dispositivos poka-yokes } \\
\text { para detectar anormalidades (erros } \\
\text { ou defeitos), os quais paralisam a } \\
\text { produção e sinalizam sua ocorrência } \\
\text { de forma sonora ou visual. }\end{array}$ & $\begin{array}{l}\text { a) } \square \text { Nem todos os } \\
\text { processos possuem } \\
\text { poka-yokes. }\end{array}$ & a) $1 \mathrm{pt}$ \\
\hline $\begin{array}{l}16 . \quad \text { Fluxo } \\
\text { unitário } \\
\text { (ONE) }\end{array}$ & $\begin{array}{l}\text { a) As peças são produzidas e } \\
\text { transportadas de modo unitário entre } \\
\text { operações, sendo que em cada } \\
\text { operação se realiza apenas o que é } \\
\text { exigido pela etapa posterior. }\end{array}$ & $\begin{array}{l}\square \square \text { Neste requisito } \\
\text { a célula esta com } \\
\text { seus } \\
\text { procedimentos } \\
\text { conforme. }\end{array}$ & a) $2 \mathrm{pts}$ \\
\hline
\end{tabular}




\begin{tabular}{|c|c|c|c|}
\hline $\begin{array}{l}17 . \\
\text { Visibilidade e } \\
\text { troca de } \\
\text { informações. } \\
\text { (VIS) }\end{array}$ & $\begin{array}{l}\text { a) Há visibilidade de todos os } \\
\text { operadores em relação a todas as } \\
\text { operações (operadores } \\
\text { equipamentos) e materiais (em fluxo } \\
\text { ou em estoque) alocados na própria } \\
\text { célula. } \\
\text { b) Todos os operadores podem se } \\
\text { comunicar verbalmente em tom de } \\
\text { voz normal. }\end{array}$ & $\begin{array}{l}\text { a) Os operadores } \\
\text { não possuem uma } \\
\text { boa visibilidade da } \\
\text { célula } \\
\text { b) Os operadores } \\
\text { não se comunicam } \\
\text { em tom de voz } \\
\text { normal }\end{array}$ & $\begin{array}{l}\text { a) } 1 \mathrm{pt} \\
\text { b) } 0 \mathrm{pts}\end{array}$ \\
\hline $\begin{array}{l}\text { 18. Tamanho e } \\
\text { forma do } \\
\text { arranjo } \\
\text { físico. (LSS) }\end{array}$ & $\begin{array}{l}\text { a) As dimensões da célula e o arranjo } \\
\text { físico permitem que todos os } \\
\text { operadores (no mínimo dois) troquem } \\
\text { materiais entre si, sendo exigido para } \\
\text { isso um deslocamento de até um } \\
\text { metro de distância. } \\
\text { b) Caso tenha apenas um operador, o } \\
\text { arranjo físico permite que a célula } \\
\text { opere com mais de um operador e } \\
\text { obedece ao atributo anterior. }\end{array}$ & $\begin{array}{l}\square \square \text { Neste requisito } \\
\text { a célula esta com } \\
\text { seus } \\
\text { procedimentos } \\
\text { conforme. }\end{array}$ & $\begin{array}{l}\text { a) } 2 \mathrm{pts} \\
\text { b) } 2 \mathrm{pts}\end{array}$ \\
\hline $\begin{array}{l}19 . \\
\text { Organização } \\
\text { em fluxo } \\
\text { dominante } \\
\text { (ODF) } \\
\end{array}$ & $\begin{array}{l}\text { a) Todos os produtos que são } \\
\text { produzidos na célula passam pelos } \\
\text { mesmos processos seguindo o mesmo } \\
\text { fluxo de produção. }\end{array}$ & $\begin{array}{l}\square \square \text { Neste requisito } \\
\text { a célula esta com } \\
\text { seus } \\
\text { procedimentos } \\
\text { conforme. }\end{array}$ & a) $2 \mathrm{pts}$ \\
\hline
\end{tabular}

Fonte: Fritzen (2013).

Quadro 9 - Tabela de pontuação das praticas de PE de acordo média aritmética dos atributos $(\mathbf{a}, \mathbf{b}, \mathbf{c}, \mathbf{d})$.

\begin{tabular}{|c|c|c|c|c|c|}
\hline \multicolumn{5}{|l|}{ Pontuação dos atributos } & \\
\hline & A & B & $\mathrm{C}$ & D & Total \\
\hline 17.Visibilidade e troca de informação (VIS) & 1 & 0 & - & - & 0,5 \\
\hline 2.Melhoria contínua $(\mathrm{CI})$ & 1 & 1 & 0 & - & 0,66 \\
\hline 3.Multifuncionalidade e prática de rodízio (MCT) & 1 & 2 & 0 & - & 1,0 \\
\hline 4.Autonomia dos operadores (WAU) & 2 & 1 & 0 & - & 1,0 \\
\hline $\begin{array}{l}\text { 12.Indicadores enxutos para a medição de desempenho } \\
\text { (LME) }\end{array}$ & 1 & - & - & - & 1,0 \\
\hline 15.Autonomação de equipamentos (EQA) & 1 & - & - & - & 1,0 \\
\hline 11.Manutenção produtiva total (TPM) & 2 & 1 & - & - & 1,5 \\
\hline 1.Trabalho em equipe liderança (TWL) & 1 & 2 & 2 & - & 1,6 \\
\hline 7.Segurança e ergonomia (SE) & 1 & 2 & 2 & - & 1,6 \\
\hline 5.Padronização do trabalho (STW) & 2 & 2 & 1 & 2 & 1,7 \\
\hline 6.Organização do local de trabalho (WHK) & 2 & 2 & 2 & - & 2,0 \\
\hline 8.Produção puxada (PULL) & 2 & 2 & 2 & - & 2,0 \\
\hline 9.Nivelamento de produção (SPR) & 2 & 2 & - & - & 2,0 \\
\hline 10.Troca rápida de ferramentas (QST) & 2 & - & - & - & 2,0 \\
\hline
\end{tabular}




\begin{tabular}{|l|c|c|c|c|c|}
\hline 13.Gestão visual do controle de produção (VPC) & 2 & 2 & - & - & 2,0 \\
\hline 14.Gestão visual do controle de qualidade (VQC) & 2 & 2 & - & - & 2,0 \\
\hline 16.Fluxo unitário (ONE) & 2 & - & - & - & 2,0 \\
\hline 18.Tamanho e forma do arranjo físico (LSS) & 2 & 2 & - & - & 2,0 \\
\hline 19.Organização em fluxo dominante (ODF) & 2 & - & - & - & 2,0 \\
\hline
\end{tabular}

Fonte: Fritzen (2012).

Conforme podemos verificar no quadro 9 a célula apresentou nove práticas de produção enxuta que são utilizadas completamente (WHK, ONE, QST, VQC, VPC, PULL, SPR, ODF, LSS) representando 47\% do total. Dez práticas que são usadas parcialmente (VIS, CI, MCT, WAU, TWL, STW, LME, EQA, SE, TPM).

Figura 5 - Resultado do modelo de relacionamento das práticas de produção enxuta.

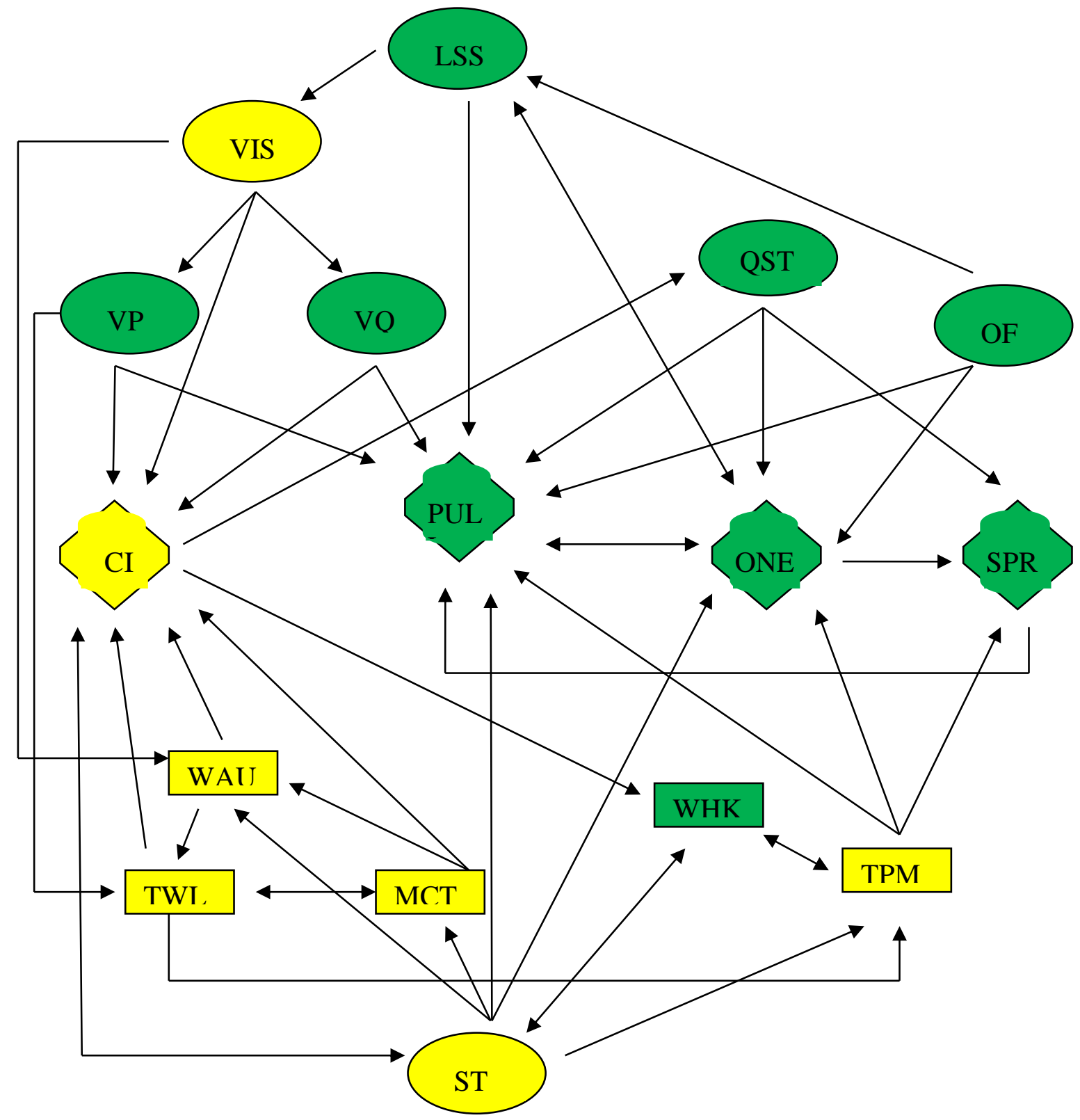


Conforme a figura 5 as práticas VIS, CI, MCT, WAU, TWL, STW e TPM foram consideradas como parciais, por alguns pontos não estarem de acordo com o estudo.

Em relação à prática VIS, dois atributos foram considerados parciais. O primeiro porque os operadores não possuem uma boa visibilidade da $\mathrm{CM}$ e o segundo porque os operadores não se comunicam verbalmente em tom de voz normal. O primeiro atributo pode impactar diretamente nos resultados das práticas VPC e VQC que são consideradas práticas conforme; pois mesmos que os quadros de controles de produção e qualidade tenham uma gestão visual e sejam visíveis aos operadores, os quadros só podem ser vistos na entrada da célula. O segundo atributo se interliga com as práticas WAU, TWL, STW, MCT e CI, em que a MCT depende diretamente das outras para um bom resultado.

A prática MCT não possui rodízio entre postos devido a problemas de qualidade. Segundo a gerência da empresa, isto acontece por que os operadores que estão fixos nos postos de trabalho conhecem muito bem as operações, e por isso têm receio de que a implementação aumente o índice não qualidade. O primeiro ponto que deveria ser tratado é a documentação desatualizada da prática STW, pois as informações corretas fazem com que os operadores não tenham dúvidas nos postos de trabalho.

Outro ponto para solucionar os problemas de qualidade, é que os problemas deveriam ser tratados através de um grupo de melhoria contínua, que é um atributo da prática CI, e que não deveria ter somente um responsável, conforme o resultado da prática TWL. Outra solução para os problemas de qualidade poderia ser a implementação do atributo de solicitação imediata para auxilio da prática WAU, em que a mesma ajudaria na comunicação interna da $\mathrm{CM}$, visto que na prática VIS foi detectado que os operadores não se comunicam verbalmente em tom de voz normal devido ao ruído de ar comprimido das inúmeras máquinas de injeção de borracha.

As práticas VIS, TWL, STW, CI, MCT, WAU citadas acima necessitam umas das outras para solucionar as questões que não estão de acordo. Como visto, a prática MCT só será conforme se os problemas de qualidade forem solucionados através das práticas VIS, TWL, STW, CI e WAU.

Outra prática que não está conforme é a TPM, por não possuir manutenção preventiva em todos os equipamentos. A TPM também pode causar problemas de qualidade que prejudicam a prática MCT. Além desta, outra prática como WHK, que é considerada conforme, pode ter resultados não desejados visto que a falta de manutenção dos equipamentos pode gerar vazamentos de óleo, prejudicando limpeza da célula.

5.5 Resultados dos indicadores da célula de manufatura

Os resultados dos indicadores de qualidade: entrega, segurança, produtividade e eficiência foram analisados durante seis meses antes da entrada do novo produto da $\mathrm{CM}$, tendo como objetivo comparar os resultados. A tabela 1 mostra o resultado da média dos seis meses analisados.

Tabela 1 - Tabela de resultados dos indicadores da célula de manufatura.

$$
\text { Resultados Metas }
$$

\section{Indicadores}

Entrega

$100 \%$

$100 \%$

Segurança

$0 \%$

$0 \%$ 


\begin{tabular}{lcc}
\hline Qualidade & $1.8 \%$ & $2 \%$ \\
Produtividade & $90 \%$ & $91 \%$ \\
Eficiência & $93 \%$ & $89 \%$ \\
\hline
\end{tabular}

Fonte: Fritzen (2013).

Os resultados dos indicadores de entrega e segurança mostraram-se satisfatórios para a empresa, atingindo as metas de $100 \%$ de entrega e de nenhum acidente na área de segurança. Comparado com os resultados do estudo da tabela 1, os atributos de planejamento e controle da produção e de segurança estão com a pontuação máxima nos seus requisitos, confirmando os resultados dos indicadores apresentados pela empresa.

Em relação ao indicador da qualidade, verificou-se que o seu índice estava dentro do especificado pela a empresa, que tem como meta $2 \%$ de sucata. Mesmo tendo bons resultados, este índice vem aumentando nos últimos anos. Esse aumento da sucata era oriundo de uma falta de manutenção preventiva em alguns equipamentos de montagem. De fato, na avaliação do uso da PE, apenas parte dos atributos da prática TPM era atendida, em função da falta de manutenção preventiva.

Tabela 2 - Tabela de resultados do mês dos indicadores de OEE e Produtividade da célula de manufatura.

\begin{tabular}{|c|c|c|c|c|c|c|c|c|c|c|c|}
\hline \multicolumn{12}{|c|}{ Monthly Performance Summary } \\
\hline \multirow{2}{*}{$\begin{array}{c}\text { KPII } \\
\text { Information }\end{array}$} & & & \multicolumn{8}{|c|}{ Day } & \multirow[b]{2}{*}{1 MIU } \\
\hline & & & \begin{tabular}{l|l|}
1 & 2 \\
\end{tabular} & \begin{tabular}{l|l}
45 & 5 \\
\end{tabular} & \begin{tabular}{|l|l|l|l|}
6 & 7 & 8 & 9 \\
\end{tabular} & \begin{tabular}{l|l}
11 & 12 \\
\end{tabular} & 13 & \begin{tabular}{|l|l|l|}
14 & 15 & 16 \\
\end{tabular} & \begin{tabular}{|l|l|l|l|l|l|}
8 & 19 & 20 & 21 & 22 & 23 \\
\end{tabular} & \begin{tabular}{|l|l|l|l|l|l|l|}
5 & 26 & 27 & 28 & 29 & 30 & 31 \\
\end{tabular} & \\
\hline \multirow{4}{*}{ OEE $(\%)$} & \multirow{4}{*}{ MM 401} & 1 & $98 \%$. $93 \%$ & & $696 \%|94 \% / 86 \%| 91 \%$ & & $93 \%$ & 888\% $83 \%$ [93\% & $89 \%$ & $|91 \%| 95 \%|98 \%| 95 \%|46 \%| 91 \%$ & $89 \%$ \\
\hline & & 2 & & & & & & & & & \\
\hline & & 3 & $79 \% / 99 \%$ & & $691 \%$ |95\%/ $98 \%$ |95\% & $\mid 791 \%$ & 98\% & $86 \%$ |99\%/ $97 \%$ & $|91 \% / 85 \%| 98 \% / 97 \% \mid 93 \%$ & $|84 \%| 76 \%|83 \%| 94 \%|95 \%| 92 \%$ & 911\% \\
\hline & & Avs & $990 \%$ 96\% & & 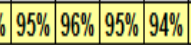 & $92 \%$ & $104 \%$ & $90 \%$ 93\% $96 \%$ & 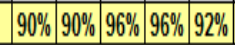 & 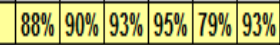 & $93 \%$ \\
\hline \multirow{4}{*}{$\begin{array}{c}\text { Productivity } \\
(\%)\end{array}$} & \multirow{4}{*}{ MM 401} & 1 & $98 \% \%$ |93\% & & $696 \%$ 94\% $806 \%$ & $87 \%$ & 93\% & 888\% $83 \%$. $93 \% \%$ & $89 \%$ |90\% $195 \%$ |93\% $87 \%$ & $|91 \%| 95 \%$ |98\% $\mid 95 \%$ |46\% $\mid 91 \%$ & $89 \%$ \\
\hline & & 2 & & & & & & & & & \\
\hline & & & $79 \%$ 99\% & & $691 \%$ 95\% $198 \%$ |95\% & $91 \%$ & \begin{tabular}{|l|l|}
$98 \%$ \\
\end{tabular} & $86 \%$ [99\% $97 \%$ & $\mid 91 \%$ 85\% $698 \%|97 \%| 93 \%$ & $|84 \%| 76 \%$ 83\% $\mid 94 \%$ |95\% $\mid 92 \%$ & 911\% \\
\hline & & Avc & $988 \%$ 96\% & & 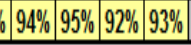 & $89 \%$ & 96\% & $87 \%$ [91\% $95 \%$ & $90 \%$ 88\% $96 \%$ 95\% $90 \%$ & $|88 \%| 86 \%|91 \%| 94 \%|71 \%| 91 \%$ & 90\% \\
\hline
\end{tabular}

Fonte: Fritzen (2013).

O resultado do indicador de eficiência encontra-se em $93 \%$, e o indicador de produtividade em $90 \%$. Conforme a tabela 2 analisou-se que, mesmo com as metas de $89 \%$ e $91 \%$, estes dois indicadores apresentaram várias paradas devido a problemas de processo e máquinas, chegando a 40 horas mensais.

Mesmo a empresa utilizando práticas de produção enxuta há anos, os resultados mostraram a importância do estudo de Saurin et al. (2011) para a CM. Com o estudo, identificou-se que todas as horas paradas ocorreram por não atendimento imediato da CM, sendo necessárias paradas maiores posteriores para atender a qualidade de produto. Um dos resultados do estudo mostrou que esta ineficiência do não atendimento da linha, prejudica o seu andamento sendo necessários dispositivos visuais, como o andon. A falta da ferramenta andon era de conhecimento da empresa e foi detectada nas auditorias, mas não se sabia o impacto causado pela a ausência da mesma, pois os resultados mensais foram sempre acima da meta.

\section{Conclusões}


O presente trabalho apresentou uma avaliação do uso de práticas de produção enxuta de uma célula de manufatura, a qual seria reprojetada em função da introdução de um novo produto. A CM em análise era a mais importante para empresa financeiramente e, por isso, uma avaliação externa se fazia necessária para evitar que o reprojeto tenha as mesmas falhas da CM atual.

Os participantes da aplicação deste método foram os operadores, chefes de produção, analistas de processo e de qualidade, que viram as principais diferenças entre os métodos de Saurin et al. (2011) e o método da empresa.

Ao analisar o método de Saurin et al. (2011) e o da empresa, chegou-se a conclusão de que era necessário incluir os itens: segurança do trabalho e ergonomia. Outra modificação incluída no trabalho foi uma tabela de pontuação das práticas de PE, gerando graus de importância dos atributos para o reprojeto da CM.

Após a aplicação, percebeu-se que algumas práticas da PE não eram usadas: Trabalho em equipe e liderança (TWL), Padronização do trabalho (STW), Melhoria contínua (CI), multifuncionalidade e práticas de rodízio (MCT), autonomia dos operadores (WAU) e visibilidade e troca de informações (VIS), Segurança e ergonomia (SE) e Automação de equipamentos (EQA). Estas práticas devem ser o foco das melhorias durante o processo de reprojeto.

$\mathrm{Na}$ análise geral do trabalho, podemos considerar que $47 \%$ das práticas de produção enxuta avaliadas no trabalho de Saurin et al. (2011), estão atingindo a pontuação máxima, deixando algumas melhorias a serem executadas para que esta célula seja considerada enxuta.

\section{Referências}

CANGÜE, F.; GODEFROID, L.; SILVA, E. Análise atual do setor automobilístico nacional. Revista Científica Symposium. v. 2, n. 1, 2004.

CONCEIÇÃO, S. Otimização do fluxo de materiais através da manufatura celular. Prod., São Paulo, v. 15, n. 2, may/aug. 2005.

CONTADOR, J. Células de manufatura. São Paulo: Departamento de engenharia de produção UNESP, 1995.

FLEURY, A. Cultura da qualidade e mudança organizacional. Revista de administração, v. 33, n. 2, p. 26-34, 1993.

GARCIA, C. Planejamento da auditoria de saúde e segurança no trabalho - OHSAS 18001. In: SIMPEP, 11., 2004, Bauru. Anais... Bauru: [s.n.], 2004

GARY, L. Developing and implementing and ergonomic audit for manufacturing. MSQA Program, n. 28, jul. 2003.

GONÇALVES FILHO, A.; ANDRADE, J.; MARINHO, M. Culture e safety management: the proposal of a model. Gestão de Produção, São Carlos, v. 18, n. 1, p. 205-220, 2011.

HYER , N.; BROWN, K. A. The discipline of real cells. Journal of operations Management, v. 17, p. 557-574, 1999.

PARK, K. S.; HAN, S. W. Performance obstacles in cellular manufacturing implementation - empirical investigation. Human factors abs ergonomics in manufacturing. [S.1.]: [s.n.], 2002.

RIANI, A. Estudo de caso: o lean manufacturing aplicado na Becton Dickinson. Engenharia de produção. Juiz de Fora: UFJF, 2006. 
RIBEIRO, J.; MEGUELATI, S. Organização de um sistema de produção em células de fabricação. Gestão da Produção, São Carlos, v. 9, n. 1, 2002.

SAURIN, T.; MARODIN, G.; RIBEIRO, J. A framework for assessing the use of lean production practices in manufacturing cells. International journal of production research, v. 49, n.11, p. 3211-3230, 2011.

SHARMA, B. P.; PATTANAIK, L. N. Implementing lean manufacturing with cellular lay out: a case study. India: Department of Production Engineering, Birla Institute of Technology, 2008.

SHAH, R.; WARD, P. T. Lean manufacturing: context, practice bundles, and a performance. Journal of Operations Management, v. 21, n. 2, 2003.

WILKES N.. Strength in agility. Professional engineering, v. 13, p. 34-35, 2000.

WOMACK, J. P.; JONES, D. T. A mentalidade enxuta nas empresas. Rio de Janeiro: Campus, 1998. 